\title{
Deregulation of miR-193b affects the growth of colon cancer cells via transforming growth factor- $\beta$ and regulation of the SMAD3 pathway
}

\author{
KAIMING WU ${ }^{1}$, ZHENXIAN ZHAO ${ }^{2}$, JUN MA $^{3}$, \\ JIANHUI CHEN ${ }^{1}$, JIANJUN PENG ${ }^{1}$, SHIBIN YANG ${ }^{1}$ and YULONG HE ${ }^{1}$ \\ Departments of ${ }^{1}$ Gastrointestinal Surgery, ${ }^{2}$ Pancreato-Biliary Surgery and ${ }^{3}$ Thoracic Surgery, \\ The First Affiliated Hospital of Sun Yat-Sen University, Guangzhou, Guangdong 510080, P.R. China
}

Received November 14, 2015; Accepted November 11, 2016

DOI: $10.3892 / \mathrm{ol} .2017 .5763$

\begin{abstract}
MicroRNA-193b (miRNA-193b) is often differentially expressed and is an important regulator of gene expression in colon cancer. The aim of the present study was to determine whether miRNA-193b affects cell growth in colon cancer and to investigate the potential underlying mechanisms. Patients with colorectal cancer $(C R C ; n=20)$ and healthy volunteers $(n=10)$ were enrolled from the Department of Gastrointestinal Surgery Center, First Affiliated Hospital of Sun Yat-Sen University (Guangzhou, China). Western blot analysis was used to evaluate the protein expression of SMAD3 and transforming growth factor- $\beta$ (TGF- $\beta$ ) in the patient samples. It was determined that miRNA-193b expression was markedly elevated in the CRC tissue samples. Furthermore, silencing of miRNA-193bin SW620 CRC cells by specific inhibitors significantly reduced the cell proliferation and induced apoptosis. In addition, the downregulation of miRNA-193b significantly activated the protein expression of SMAD 3 and TGF- $\beta$, and promoted caspase- 3 activity in SW620 cells. The results of the present study suggested that the deregulation of miRNA-193b may affect cell growth in colon cancer via the TGF- $\beta$ and SMAD3 signaling pathways.
\end{abstract}

\section{Introduction}

Colorectal cancer (CRC) is a malignant type of cancer with an increasing morbidity (1). Recent data from the International Agency for Research on Cancer indicated that the number of novel cases of lung cancer in 2012 reached 14.1 million (2).

Correspondence to: Dr Shibin Yang, Department of Gastrointestinal Surgery, The First Affiliated Hospital of Sun Yat-Sen University, 58 Zhong Shan Er Road, Guangzhou, Guangdong 510080, P.R. China

E-mail: shibinyang2200@163.com

Key words: microRNA-193b, colon cancer, transforming growth factor- $\beta$, SMAD3
With the improvement of living standards, and changes in lifestyle and the environment, the morbidity of colon cancer is increasing annually (3). Colon cancer has emerged as a serious public health problem, which threatens the health and lives of patients and is a social burden (4). Therefore, further studies on the etiology and pathogenesis of colon cancer are essential (5).

MicroRNA (miRNA; miR) is an endogenous, non-coding, single-stranded small RNA, which is typically composed of 21-25 nucleotides (6). Numerous studies have suggested that miRNA may participate in certain pathophysiological procedures, including cell differentiation, proliferation, apoptosis, multi-drug resistance, fat metabolism, oncogenesis and metastasis (7). Mutation and loss of expression of miRNAs have been closely associated with various types of tumors (8). In breast cancer, colon cancer and glioma, miRNA-21 was able to promote the occurrence and progression of tumors by stimulating cellular invasion and metastasis (8). Similarly, miRNA-10b was shown to promote the invasion and metastasis of breast cancer cells (9). The let-7 miRNA was reported to exert its carcinostatic effect by inhibiting cell adhesion, metastasis and invasion (10). A recently identified miRNA, miRNA-193b, also has an essential role in various types of tumors (11).

TGF- $\beta$, which has a relative molecular mass of $25 \mathrm{kDa}$, is composed of dimers and is located at chromosome 19ql3.1 (12). TGF- $\beta$ is cytokine that exerts various biological effects under physiological and pathological conditions (13). When TGF- $\beta$ is activated, it is recognized by its receptors and exerts its biological functions through the SMAD or non-SMAD signaling pathways (14). Recent studies have revealed that TGF- $\beta$ is highly expressed in various types of tumors (breast cancer, liver cancer, lung cancer), and participates in invasion and metastasis through regulating the extracellular matrix and angiogenesis, and by promoting immune evasion (15-17). The current study aimed to determine whether miRNA-193b is able to affect cell growth in colon cancer, and to investigate the possible underlying mechanisms.

\section{Materials and methods}

Clinical tissue samples. Human patients with CRC $(\mathrm{n}=20)$ and healthy volunteers $(n=10)$ were enrolled at the Department of 
Gastrointestinal Surgery, The First Affiliated Hospital of Sun Yat-Sen University (Guangzhou, China) from May-July 2013. Cancerous tissues, adjacent mucosal tissues and venous blood were collected from the patients with CRC during surgery, and venous blood was obtained from healthy volunteers. Informed consent was obtained from all participants. The clinical information for all patients and volunteers was recorded. The Institutional Ethics Committee of The First Affiliated Hospital of Sun Yat-Sen University approved the study protocol.

Cell culture and cell proliferation assay. IEC-6 enterocytes andSW620, SW480 and HT29 colon cancer cells were purchased from the Type Culture Collection of the Chinese Academy of Sciences (Shanghai, China), and cultured in Dulbecco's modified Eagle's medium (Gibco ${ }^{\circledR}$; Thermo Fisher Scientific, Inc., Waltham, MA, USA) supplemented with $10 \%$ fetal bovine serum $\left(\mathrm{Gibco}^{\circledR}\right)$ at $37^{\circ} \mathrm{C}$ in a humidified atmosphere containing $5 \% \mathrm{CO}_{2}$. All cells $\left(1 \times 10^{4}\right)$ were seeded into 96 -well tissue culture plates and incubated at $37^{\circ} \mathrm{C}$. Subsequently, $20 \mu 1$ MTT $(50 \mathrm{mg} / \mathrm{ml})$ was added to each well and the wells were cultured at $37^{\circ} \mathrm{C}$ for $4 \mathrm{~h}$. Old medium was absorbed and $200 \mu \mathrm{l}$ DMSO was added to each well then agitated at room temperature for $20 \mathrm{~min}$. The absorbance was measured at $490 \mathrm{~nm}$ using an ELX-800 microplate assay reader (BioTek Instruments, Inc., Winooski, VT, USA).

Reverse transcription-quantitative polymerase chain reaction $(R T-q P C R)$. Total RNA was isolated from cancer tissues, adjacent mucosal tissues, venous blood and cells using TRIzol ${ }^{\circledR}$ reagent (Invitrogen; Thermo Fisher Scientific, Inc.). DNase was used to remove contaminating DNA (Takara Biotechnology Co., Ltd., Dalian, China) and Total RNA (1 $\mu \mathrm{g})$ was then reverse-transcribed into cDNA using M-MLV reverse transcriptase in the presence of oligo (dT) $(1 \mathrm{ng}$; Takara Biotechnology Co., Ltd.) (12-18). A StepOne ${ }^{\mathrm{TM}}$ Real-Time PCR System (Applied Biosystems; Thermo Fisher Scientific, Inc.) was used to perform RT-qPCR with ABI PRISM 7500 Fast Real-Time PCR system (Applied Biosystems; Thermo Fisher Scientific, Inc.), as follows: $10 \mathrm{~min}$ at $95^{\circ} \mathrm{C}$ for the initial denaturation, followed by 40 cycles at $95^{\circ} \mathrm{C}$ for $15 \mathrm{sec}$, $58^{\circ} \mathrm{C}$ for $30 \mathrm{sec}$ and $72^{\circ} \mathrm{C}$ for $30 \mathrm{sec}$. The primer sequences were as follows: miRNA-193b forward, 5'-TGGCGTTTC TGGTTTCTCTT-3' and reverse, 5'-CGCACCTTTTCTCCT CATTT-3'; and U6 forward, 5'-GTGCTCGCTTCGGCAGCA CATATAC-3' and reverse, 5'-AAAAATATGGAACGCTCA CGAATTTG-3'. miRNA-193b was obtained using the $2^{-\Delta \Delta C q}$ method.

Transfection. The sequence of the small interfering (si)RNA targeting miRNA-193b (final concentration, $100 \mathrm{nM}$ ) was 5'-AGCGGGACUUUGAGGCCAGUU-3' and that of the scrambled control was 5'-UUGUACUACACAAAAGUA CUG-3'. The siRNASMAD3 siRNA sequences (final concentration, $200 \mathrm{nM}$ ) were sense, 5'-UAGAACUGGUGUCUC UACUTT-3' and antisense, 5'-AGUAGAGACACCAGUUCU ATT-3'. Cell transfections were performed using INTERFERin $^{\circledR}$ reagent (Polyplus Transfection ${ }^{\circledR}$, Illkirch, France) and transfected at $48 \mathrm{~h}$ at other study.
Flow cytometry. The transfected cells were seeded into 6-well tissue culture plates $\left(1-2 \times 10^{6}\right)$ and incubated at $37^{\circ} \mathrm{C}$. Annexin V-fluorescein isothiocyanate (10 $\mu \mathrm{l}$; Sigma-Aldrich; Merck Millipore, Darmstadt, Germany) and $5 \mu 1$ propidium iodide were added to each well and cultured at $37^{\circ} \mathrm{C}$ for $4 \mathrm{~h}$. The rate of cell apoptosis was analyzed using a FACSCalibur Flow Cytometry System (BD Biosciences, San Jose, CA, USA).

Determination of caspase-3 activity. Transfected cells $\left(1 \times 10^{3}\right.$ cell/well) were seeded into 96-well tissue culture plates at $37^{\circ} \mathrm{C}$. Ac-DEVD-pNA (10 $\mu 1$; Beyotime Institute of Biotechnology, Haimen, China) for caspase-3 was added to each well and the plates were incubated for $6 \mathrm{~h}$ at $37^{\circ} \mathrm{C}$. Caspase-3 activity was evaluated at $405 \mathrm{~nm}$ using an ELISA reader (Bio-Rad Laboratories, Inc., Hercules, CA, USA).

Western blot analysis. All transfected cells were seeded into 6-well tissue culture plates $\left(1-2 \times 10^{6}\right)$ at $37^{\circ} \mathrm{C}$ and lysed using $200 \mu \mathrm{l}$ protein (RIPA; Sangon Biotech Co., Ltd., Shanghai, China). The protein concentration was determined using a Bicinchoninic Acid Protein Assay kit (Sangon Biotech Co., Ltd.). The proteins were separated using 12\% SDS-PAGE and transferred onto nitrocellulose membranes (Bio-Rad Laboratories, Inc.). Following blocking of the membranes using 5\% nonfat milk in TBST, the membranes were incubated with anti-p-SMAD3 (\#9520; dilution 1:2,000; Cell Signaling Technology, Inc., Danvers, MA, USA), anti-TGF- $\beta$ (\#3709; dilution, 1:2,000; Cell Signaling Technology Inc.) and $\beta$-actin (\#4970; dilution 1:2,000; Cell Signaling Technology, Inc.) antibodies at $4^{\circ} \mathrm{C}$ overnight. Following washing with TBST, the membranes were incubated with a goat anti-rabbit secondary antibody (\#A16110; 1:5,000; Pierce; Thermo Fisher Scientific, Inc.) at $37^{\circ} \mathrm{C}$ for $1 \mathrm{~h}$, and the blots were detected using an enhanced chemiluminescent reagent (\#G-21234; Pierce; Thermo Fisher Scientific, Inc.) and quantified using Image Lab 3.0 (Bio-Rad Laboratories, Inc.).

Statistical analysis. Continuous variables are expressed as the mean \pm standard error of the mean. All statistical analyses were carried out using the SPSS 16.0 statistical software package (SPSS, Inc., Chicago, IL, USA) and with the Student's $t$-test. $\mathrm{P}<0.05$ was considered to indicate a statistically significant result.

\section{Results}

miRNA-193b expression in human patients with CRC and healthy volunteers. The expression of miRNA-193b in human patients with CRC and healthy volunteers was evaluated using RT-qPCR. Furthermore, the expression of miRNA-193b in cancer tissues was significantly increased compared with the adjacent mucosa $(\mathrm{P}<0.01$; Fig. 1$)$.

miRNA-193b expression in human CRC cell lines. The expression of miRNA-193bin IEC-6, SW620, SW480 and HT29 cells was determined using RT-qPCR. As presented in Fig. 2, the expression of miRNA-193b in IEC-6 cells was the lowest of all the cells. The expression of miRNA-193b in HT29 cells was low, as compared with that in SW620 andSW480 cells (Fig. 2). The expression of SW620 cells was medium in SW620, 


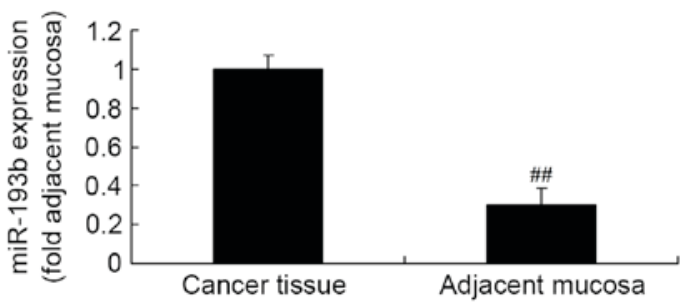

Figure 1. miR-193b expression in human patients with CRC and healthy volunteers. The expression levels of miR-193b in cancer tissues and adjacent mucosa were evaluated using reverse transcription-quantitative polymerase chain reaction. ${ }^{\# \prime} \mathrm{P}<0.01$ vs. the cancer tissue group. miR, microRNA; $\mathrm{CRC}$, colorectal cancer.

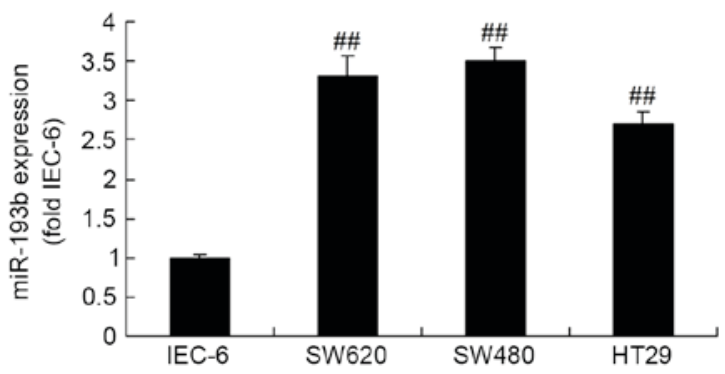

Figure 2. miR-193b expression in human colorectal cancer cell lines was determined using reverse transcription-quantitative polymerase chain reaction. ${ }^{\# \#} \mathrm{P}<0.01$ vs. the IEC- 6 cells. miR, microRNA.

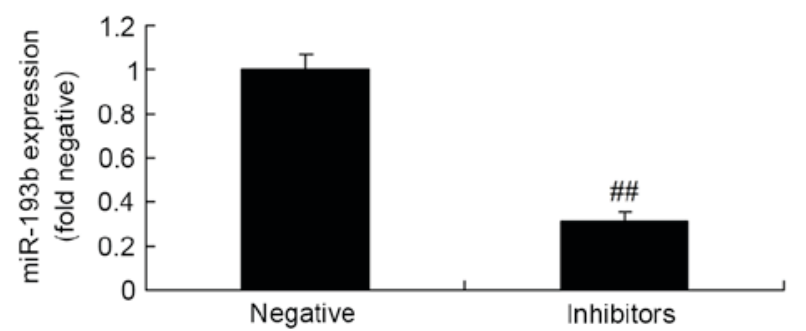

Figure 3. Effect of the deregulation of miR-193b on the expression of miR-193b in SW620 cells. ${ }^{\# \#} \mathrm{P}<0.01$ vs. the negative group. miR, microRNA.

SW480 and HT29 cells; therefore, SW620 cells were selected for further use in the present study.

Deregulation of miRNA-193b affects the expression of miRNA-193b in SW620 cells. Negative controls or miR-193b siRNAs were transiently transfected into SW620 cells, in order to investigate the expression profile of miRNA-193b in SW620 cells. The results revealed miR-193b inhibitors significantly inhibited the expression of miRNA-193b in SW620 cells, as compared with in the negative control group (P<0.01; Fig. 3).

Deregulation of miRNA-193b affects the proliferation of SW620 cells. The present study investigated how the deregulation of miR-193b may affect the proliferation of SW620 cells using MTT assays. Fig. 4 demonstrates that miRNA-193b inhibitors significantly reduced the proliferation of SW620 cells after 24 or $48 \mathrm{~h}$, as compared with the negative control cells $(\mathrm{P}<0.01$; Fig. 4).

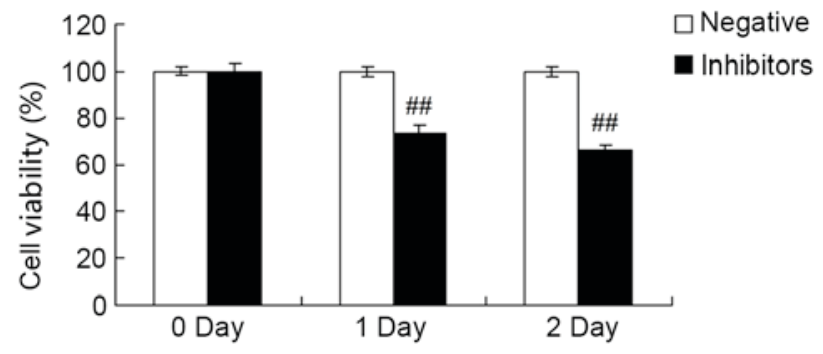

Figure 4. Effect of the deregulation of miR-193b on the proliferation of SW620 cells. The proliferation of SW620 cells transfected with miR-193 inhibitors or negative control was determined using MTT assays. ${ }^{\# \#} \mathrm{P}<0.01$ vs. the negative group. miR, microRNA.

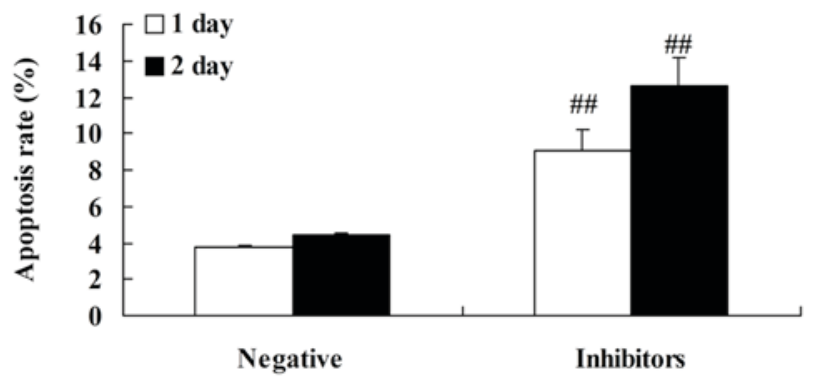

Figure 5. Effect of the deregulation of miR-193b on the apoptosis of SW620 cells. The apoptosis of SW620 cells transfected with miR-193 inhibitors or negative control was determined by flow cytometry. ${ }^{\# \#} \mathrm{P}<0.01 \mathrm{vs}$. the negative group. miR, microRNA.

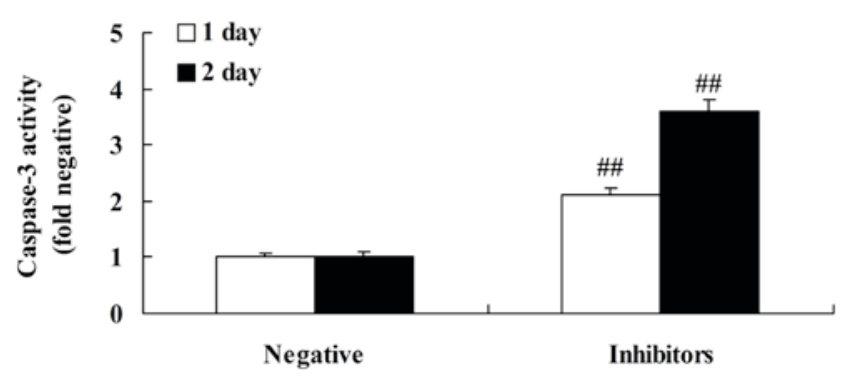

Figure 6. Effect of the deregulation of miR-193b on caspase-3 activity in SW620 cells. ${ }^{\#} \mathrm{P}<0.01$ vs. the negative group. miR, microRNA.

Deregulation of miRNA-193b affects the apoptosis of SW620 cells. In order to explore how the deregulation of miRNA-193b may affect the rate of apoptosis in SW620 cells, the apoptosis rate of SW620 cells was explored using flow cytometry. As shown in Fig. 5, a significant increase in the rate of apoptosis of SW620 cells was observed at 24 and $48 \mathrm{~h}$ following transfection with miRNA-193b inhibitors, as compared with the negative control group $(\mathrm{P}<0.01)$.

Deregulation of miRNA-193b affects caspase-3 activity in SW620 cells. To determine whether the deregulation of miRNA-193b is able to affect caspase-3 activity in SW620 cells, the caspase-3 activity in SW620 cells was detected. The downregulation of miRNA-193b expression markedly enhanced caspase- 3 activity after 24 and $48 \mathrm{~h}$ in SW620 cells, as compared with the negative control cells $(\mathrm{P}<0.01$; Fig. 6). 
A

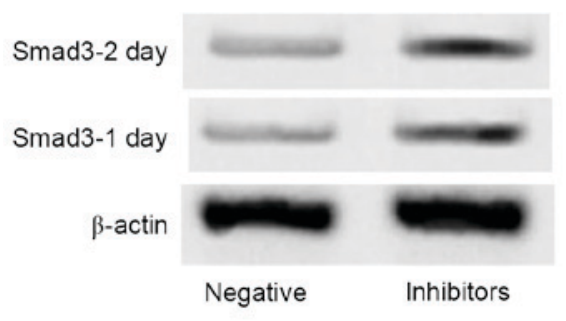

B

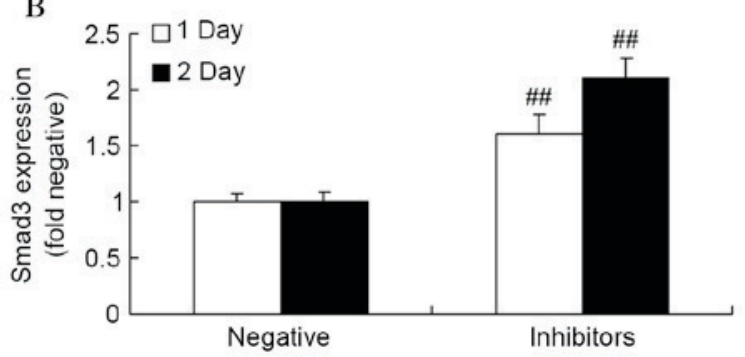

Figure 7. Effect of the deregulation of miR-193b on the SMAD3 signaling pathway inSW620 cells. The effect of the deregulation of miR-193b on SMAD3 protein expression levels in SW620 cells was determined using (A) western blot analysis and (B) densitometric analysis. ${ }^{\# \#} \mathrm{P}<0.01 \mathrm{vs.}$. the negative group. miR, microRNA.

A

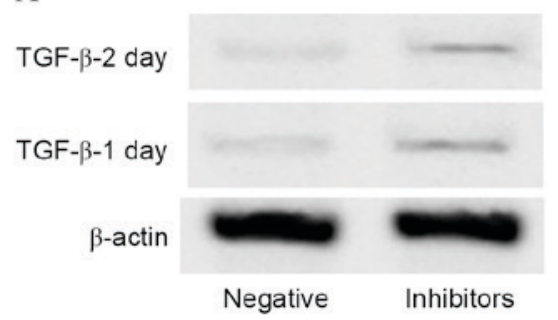

B

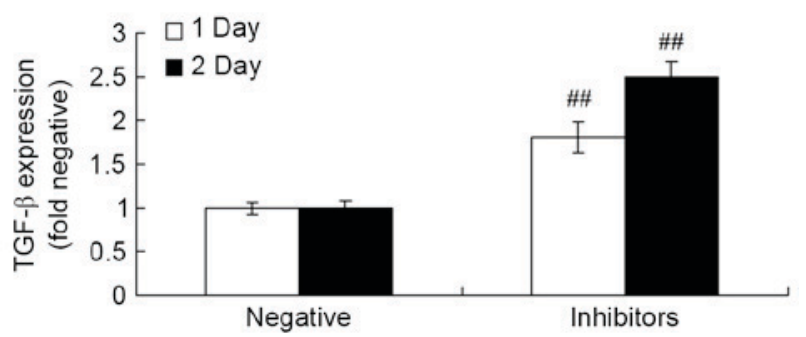

Figure 8. Effect of the deregulation of miR-193b on the TGF- $\beta$ signaling pathway in SW620 cells. The effect of the deregulation of miR-193b on TGF- $\beta$ protein expression in SW620 cells was determined using (A) western blot analysis and (B) densitometric analysis. ${ }^{\# \#} \mathrm{P}<0.01$ vs. the negative group. miR, microRNA; TGF- $\beta$, transforming growth factor $-\beta$.
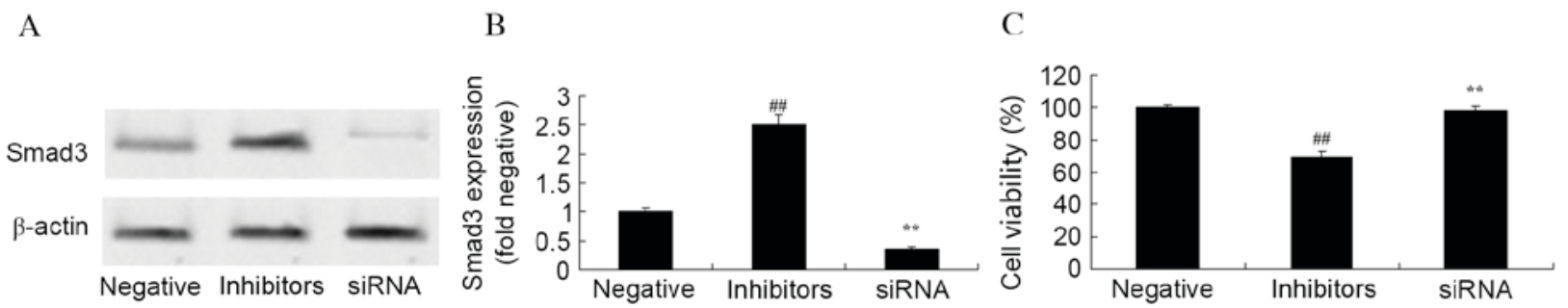

Figure 9. Effect of the deregulation of SMAD3 on the growth of SW620 cells. The effect of the deregulation of SMAD3 on its protein expression levels in SW620 cells was determined using (A) western blot analysis and (B) densitometric analysis. (C) The proliferation of SW620 cells transfected with miR-193b siRNA alone or miR-193b siRNA and siRNA targeting SMAD3. ${ }^{\# \#} \mathrm{P}<0.01$ vs. the negative group; ${ }^{* *} \mathrm{P}<0.01$ vs. the inhibitors group. miR, microRNA; siRNA, small interfering RNA.

Deregulation of miRNA-193b affects the SMAD3 signaling pathway in SW620 cells. The effect of miRNA-193b on the SMAD3 signaling pathway in SW620 cells was evaluated by western blot analysis. The downregulation of miRNA-193b expression significantly activated the protein expression of SMAD3 in SW620 cells, as compared with the negative control cells $(\mathrm{P}<0.01$; Fig. 7$)$.

Effect of miRNA-193b deregulation on the TGF- $\beta$ signaling pathway in SW620 cells. In order to explore the effect of miRNA-193b deregulation on TGF- $\beta$ expression in SW620 cells, negative controls and miR-193b inhibitors were transiently transfected into SW620 cells and western blotting was performed. The results revealed that miR-193b inhibitors significantly promoted the protein expression of TGF- $\beta$ in SW620 cells, as compared with the negative control cells ( $\mathrm{P}<0.01$; Fig. 8).
Deregulation of SMAD3 affects cell growth in SW620 cells. To determine the effect of SMAD3 deregulation on the growth of SW620 cells, the cells were transfected with miRNA-193b siRNAs alone or with miRNA-193b siRNAs and siRNA targeting SMAD3, and the protein expression of SMAD3 and the cell proliferation were each evaluated. As presented in Fig. 9A and B, siRNA targeting SMAD3 significantly reduced SMAD3 protein expression levels in SW620 cells, as compared with those in the miRNA-193b inhibitors group $(\mathrm{P}<0.01)$. Furthermore, silencing of SMAD3 significantly suppressed the miRNA-193b-mediated reduction of the proliferation of SW620 cells $(\mathrm{P}<0.01$; Fig. 9C).

\section{Discussion}

Colon cancer is a common type of malignant cancer, with its morbidity and mortality rates ranking third worldwide (18). 
Colon cancer is characterized by various genetic and epigenetic changes (19), as well as molecular alterations. However, further studies are required to identify novel therapeutic targets to develop new treatment strategies (20). In the present study, the expression of miRNA-193b in human patients with CRC was determined to be high, as compared with healthy volunteers. The expression of miR-193b in cancer tissues was also high, as compared with the adjacent mucosa. Furthermore, it was demonstrated that the expression of miRNA-193b in HT29 cells was low compared within SW620 and SW480 cells.

As an important regulatory factor, miRNA-193b is located on chromosome 16 and participates in the pathological processes of cancer (21). In a previous study, the expression of miR-193b-3p was significantly downregulated in patients with myotonic dystrophy type-2 (22). In the current study, compared with the serum miRNA expression levels in healthy patients, the expression of miRNA-193b in patients with septicemia was significantly altered. In addition, miRNA-193b was observed to be significantly decreased in adipose tissues, and participated in the formation of white adipose tissue via a series of transduction factors (23). miRNA-193b is also considered to have an important role in tumor metastasis, drug susceptibility and DNA methylation (24). miRNA-193b exhibited low expression levels in non-small cell lung cancer tissues, and the overexpression of miRNA-193b was revealed to significantly reduce the proliferation, invasion and metastatic capacity of A549 cells (25). The present study demonstrated that miRNA-193b inhibitors were able to effectively reduce cell proliferation, increase apoptosis and enhance caspase-3 activity in SW620 cells. Yang et al (7) demonstrated that miRNA-193b was able to suppress breast cancer progression. $\mathrm{Mu}$ et al (26) reported that the downregulation of miR-193b may be used as a novel and promising prognostic marker in gastric cancer.

The TGF- $\beta$ signaling pathway is an important factor in the regulation of certain cellular biological behaviors. Typically, TGF- $\beta$ exhibits tumor suppressive ability and promotes cell differentiation (23). However, during the malignant progression of a tumor, TGF- $\beta$ may facilitate malignant progression by promoting cell proliferation, invasion and metastasis, enabling immune evasion and altering the cellular microenvironment (27). TGF- $\beta$ induces the epithelial-mesenchymal transition via the SMAD signaling pathway, and sometimes the Ras signaling pathway (27). Numerous studies have suggested that TGF- $\beta$ modulates the expression of c-myc via the classical SMAD signaling pathway, in order to regulate the proliferation of cells (28). The results of the present study demonstrated that miR-193b inhibitors significantly promoted the protein expression of TGF- $\beta$ in SW620 cells. Iwamoto et al (29) reported that the downregulation of miR-193b induced the expression of urokinase-type plasminogen activator via the TGF- $\beta$ signaling pathway.

SMAD3 is a key signaling protein in the TGF- $\beta 1$ signaling pathway (30). Following its transcription, the phosphorylation of various proteins determines the functions of the TGF- $\beta 1$ signaling pathway (31). When the TGF- $\beta 1 /$ SMAD3 signaling pathway is activated, the expression levels of SMAD3 in the cytoplasm are increased (27). The current study demonstrated that the downregulation of miRNA-193b significantly activated the protein expression of SMAD3 in SW620 cells, and that
SMAD3 silencing suppressed the miRNA inhibitor-mediated reduction in the proliferation of SW620 cells. Zhong et al (32) reported that miRNA-193b promotes cell proliferation via the SMAD3 and TGF- $\beta$ signaling pathways in colon cancer.

In conclusion, the present study demonstrated that miRNA-193b was significantly overexpressed in colon cancer. The silencing of miRNA-193 in SW620 cells was revealed to induce the SMAD3 and TGF- $\beta 1$ signaling pathway in colon cancer. The results of the present study suggest that miRNA-193b maybe a tumor oncogene associated with the activation of cell growth in colon cancer via the TGF- $\beta 1 /$ SMAD3 signaling pathways. Therefore, miRNA-193b may be considered for use in the development of miRNA-based therapies in the future.

\section{References}

1. Yamaguchi K, Taniguchi H, Komori A, Narita Y, Nitta S, Nomura M, Kadowaki S, Takahari D, Ura T, Andoh M, et al: A single-arm phase II trial of combined chemotherapy with S-1, oral leucovorin, and bevacizumab in heavily pre-treated patients with metastatic colorectal cancer. BMC Cancer 15: 601, 2015.

2. Nishina T, Takano Y, Denda T, Yasui H, Takeda K, Ura T, Esaki T, Okuyama Y, Kondo K, Takahashi Y, et al: A phase II clinical study of mFOLFOX6 plus bevacizumab as first-line therapy for Japanese advanced/recurrent colorectal cancer patients. Jpn J Clin Oncol 43: 1080-1086, 2013.

3. Quere P, Facy O, Manfredi S, Jooste V, Faivre J, Lepage C and Bouvier AM: Epidemiology, management, and survival of peritoneal carcinomatosis from colorectal cancer: A population-based study. Dis Colon Rectum 58: 743-752, 2015.

4. Avallone A, Pecori B, Bianco F, Aloj L, Tatangelo F, Romano C, Granata V, Marone P, Leone A, Botti G, et al: Critical role of bevacizumab scheduling in combination with pre-surgical chemo-radiotherapy in MRI-defined high-risk locally advanced rectal cancer: Results of the BRANCH trial. Oncotarget 6: 30394-30407, 2015.

5. Brule SY, Jonker DJ, Karapetis CS, O'Callaghan CJ, Moore MJ, Wong R, Tebbutt NC, Underhill C, Yip D, Zalcberg JR, et al: Location of colon cancer (right-sided versus left-sided) as a prognostic factor and a predictor of benefit from cetuximab in NCIC CO.17. Eur J Cancer 51: 1405-1414, 2015.

6. Sha D, Lee AM, Shi Q, Alberts SR, Sargent DJ, Sinicrope FA and Diasio RB: Association study of the let-7 miRNA-complementary site variant in the 3' untranslated region of the KRAS gene in stage III colon cancer (NCCTG N0147 Clinical Trial). Clin Cancer Res 20: 3319-3327, 2014.

7. Yang IP, Tsai HL, Huang CW, Huang MY, Hou MF, Juo SH and Wang JY: The functional significance of microRNA-29c in patients with colorectal cancer: A potential circulating biomarker for predicting early relapse. PLoS One 8: e66842, 2013.

8. Lawrie $\mathrm{CH}$ : MicroRNAs and lymphomagenesis: A functional review. Br J Haematol 160: 571-581, 2013.

9. Fkih M'hamed I, Privat M, Ponelle F, Penault-Llorca F, Kenani A and Bignon YJ: Identification of miR-10b, miR-26a, miR-146a and miR-153 as potential triple-negative breast cancer biomarkers. Cell Oncol (Dordr) 38: 433-442, 2015.

10. Dou R, Nishihara R, Cao Y, Hamada T, Mima K, Masuda A, Masugi Y, Shi Y, Gu M, Li W, et al: MicroRNA let-7, T cells, and patient survival in colorectal cancer. Cancer Immunol Res 4: 927-935, 2016.

11. Jamali Z, Asl Aminabadi N, Attaran R, Pournagiazar F, Ghertasi Oskouei $\mathrm{S}$ and Ahmadpour F: MicroRNAs as prognostic molecular signatures in human head and neck squamous cell carcinoma: A systematic review and meta-analysis. Oral Oncol 51: 321-331, 2015

12. Ji H, Tang H, Lin H, Mao J, Gao L, Liu J and Wu T: Rho/Rock cross-talks with transforming growth factor- $\beta /$ Smad pathway participates in lung fibroblast-myofibroblast differentiation. Biomed Rep 2: 787-792, 2014.

13. Miguchi M, Hinoi T, Shimomura M, Adachi T, Saito Y, Niitsu H, Kochi M, Sada H, Sotomaru Y, Ikenoue T, et al: Gasdermin C is upregulated by inactivation of transforming growth factor $\beta$ receptor type II in the presence of mutated apc, promoting colorectal cancer proliferation. PLoS One 11: e0166422, 2016. 
14. Tian A, Ma H, Zhang R, Tan W, Wang X, Wu B, Wang J and Wan C: Interleukin17A promotes postoperative cognitive dysfunction by triggering $\beta$-amyloid accumulation via the transforming growth factor- $\beta$ (TGF $\beta$ )/smad signaling pathway. PLoS One 10: e0141596, 2015.

15. Xu J, Lamouille S and Derynck R: TGF-beta-induced epithelial to mesenchymal transition. Cell Res 19: 156-172, 2009.

16. Lyu X, Fang W, Cai L, Zheng H, Ye Y, Zhang L, Li J, Peng H, Cho WC, Wang E, et al: TGFbetaR2 is a major target of miR-93 in nasopharyngeal carcinoma aggressiveness. Mol Cancer 13: 51, 2014.

17. Bellomo C, Caja L and Moustakas A: Transforming growth factor $\beta$ as regulator of cancer stemness and metastasis. $\mathrm{Br} \mathrm{J}$ Cancer 115: 761-769, 2016.

18. Song X, Kim SY and Lee YJ: The role of Bcl-xL in synergistic induction of apoptosis by mapatumumab and oxaliplatin in combination with hyperthermia on human colon cancer. Mol Cancer Res 10: 1567-1579, 2012.

19. Gorczyca AM, He K, Xun P, Margolis KL, Wallace JP, Lane D, Thomson C, Ho GY, Shikany JM and Luo J: Association between magnesium intake and risk of colorectal cancer among postmenopausal women. Cancer Causes Control 26: 1761-1769, 2015.

20. Kim IY, Kim BR and Kim YW: The short-term and oncologic outcomes of laparoscopic versus open surgery for T4 colon cancer. Surg Endosc 30: 1508-1518, 2016.

21. Long J, Ji Z, Jiang K, Wang Z and Meng G: miR-193b modulates resistance to doxorubicin in human breast cancer cells by downregulating MCL-1. Biomed Res Int 2015: 373574, 2015.

22. Greco S, Perfetti A, Fasanaro P, Cardani R, Capogrossi MC, Meola G and Martelli F: Deregulated microRNAs in myotonic dystrophy type 2. PLoS One 7: e39732, 2012.

23. Hou C, Yang Z, Kang Y, Zhang Z, Fu M, He A, Zhang Z and Liao W: MiR-193b regulates early chondrogenesis by inhibiting the TGF-beta2 signaling pathway. FEBS Lett 589: 1040-1047, 2015.

24. Gao XN,Lin J, GaoL,Li YH, Wang LL and YuL: MicroRNA-193b regulates c-Kit proto-oncogene and represses cell proliferation in acute myeloid leukemia. Leuk Res 35: 1226-1232, 2011.

25. Hu H, Li S, Liu J and Ni B: MicroRNA-193b modulates proliferation, migration, and invasion of non-small cell lung cancer cells. Acta Biochim Biophys Sin (Shanghai) 44: 424-430, 2012.
26. Mu YP, Tang S, Sun WJ, Gao WM, Wang M and Su XL: Association of miR-193b down-regulation and miR-196a up-regulation with clinicopathological features and prognosis in gastric cancer. Asian Pac J Cancer Prev 15: 8893-8900, 2014.

27. Buczek ME, Miles AK, Green W, Johnson C, Boocock DJ, Pockley AG, Rees RC, Hulman G, van Schalkwyk G, Parkinson R, et al: Cytoplasmic PML promotes TGF- $\beta$-associated epithelial-mesenchymal transition and invasion in prostate cancer. Oncogene 35: 3465-3475, 2016.

28. Li Y, Jiang F, Liu Q, Shen J, Wang X, Li Z, Zhang J and Lu X: Inhibition of the cancer stem cells-like properties by arsenic trioxide, involved in the attenuation of endogenous transforming growth factor beta signal. Toxicol Sci 143: 156-164, 2015

29. Iwamoto N, Vettori S, Maurer B, Brock M, Pachera E, Jüngel A, Calcagni M, Gay RE, Whitfield ML, Distler JH, et al: Downregulation of miR-193b in systemic sclerosis regulates the proliferative vasculopathy by urokinase-type plasminogen activator expression. Ann Rheum Dis 75: 303-310, 2016

30. Casari A, Schiavone M, Facchinello N, Vettori A, Meyer D, Tiso N, Moro E and Argenton F: A Smad3 transgenic reporter reveals TGF-beta control of zebrafish spinal cord development. Dev Biol 396: 81-93, 2014.

31. Park BV, Freeman ZT, Ghasemzadeh A, Chattergoon MA, Rutebemberwa A, Steigner J, Winter ME, Huynh TV, Sebald SM, Lee SJ, et al: TGF 31 -mediated SMAD3 enhances PD-1 expression on antigen-specific T cells in cancer. Cancer Discov 6: 1366-1381, 2016.

32. Zhong Q, Wang T, Lu P, Zhang R, Zou J and Yuan S: miR-193b promotes cell proliferation by targeting Smad3 in human glioma. J Neurosci Res 92: 619-626, 2014. 